\title{
Chromosome polymorphism in Ancistrus cuiabae Knaack, 1999 (Siluriformes: Loricariidae: Ancistrini)
}

\author{
Sandra Mariotto ${ }^{1}$, Liano Centofante ${ }^{2}$, Carlos S. Miyazawa², Luiz Antonio Carlos Bertollo ${ }^{1}$ \\ and Orlando Moreira Filho ${ }^{1}$
}

Cytogenetic and FISH analyses were performed in 30 Ancistrus cuiabae specimens from a bay near the town of Poconé, in the Pantanal of Mato Grosso, Brazil. The observed diploid number was $2 \mathrm{n}=34$ chromosomes for both sexes and three distinct katyotypic formulae were found, namely cytotype A (20m, 8sm, 6st, Fundamental Number/FN = 68; 6 males and 11 females), cytotype B (19m, 8sm, 6st, 1a, FN = 67; 8 males and 4 females) and cytotype C (18m, 8sm, 6st, 2a, FN = 66; a single male). NORs's analyses showed that these regions were located in distinct sites on the NOR-bearing chromosome pair, according to cytotypes. Thus, in cytotype A, NORs were located in the terminal region of the short arm of the second metacentric chromosome pair; in cytotype B, they were detected in the short arm of the metacentric chromosome and interstitially on the acrocentric chromosome and, in cytotype C, NORs were observed in the interstitial region of the acrocentric chromosome pair. C-positive heterochromatic bands were adjacent to the rDNA sites in the corresponding chromosomes. Thus, the chromosomal polymorphism of $A$. cuiabae was probably originated through a pericentric inversion in chromosome pair $\mathrm{n}^{\circ} 2$ involving the NOR sites, which represents a novelty in the Ancistrini tribe. The results also broaden the knowledge of the chromosomal evolution in Ancistrus, the most derived genus of the Ancistrini tribe.

Foram analisados, com técnicas convencionais de citogenética e FISH, 30 exemplares da espécie Ancistrus cuiabae da baía Arrombado, próximo a Poconé, Pantanal do Mato Grosso. Foram observadas metáfases com número diploide $2 \mathrm{n}=34$ cromossomos para ambos os sexos e três fórmulas cariotípicas distintas, aqui denominadas de citótipo A, verificado em 06 machos e 11 fêmeas (20m, 8sm, 6st, Número Fundamental, NF = 68); citótipo B, em 08 machos e 04 fêmeas (19m, 8sm, 6st, 1a, NF = 67) e citótipo $\mathrm{C}$ em apenas 01 macho $(18 \mathrm{~m}, 8 \mathrm{sm}, 6 \mathrm{st}, 2 \mathrm{a}, \mathrm{NF}=66)$. As NORs confirmaram os distintos citótipos verificados, além de evidenciar que os cromossomos portadores de rDNA são os que representam o polimorfismo na espécie Ancistrus cuiabae. No citótipo A, as NORs foram verificadas na região terminal do braço curto do segundo par de cromossomos metacêntricos; no citótipo B, foram evidenciadas no segundo par, heteromórfico, no braço curto do cromossomo metacêntrico e intersticial no seu homólogo acrocêntrico; no citótipo C as NORs foram observadas na região intersticial num par de cromossomos acrocêntricos. A análise da heterocromatina constitutiva evidenciou blocos discretos adjacentes ao rDNA no segundo par de cromossomos de ambos os citótipos. Uma provável inversão pericêntrica é a hipótese proposta para a origem deste polimorfismo na espécie Ancistrus cuiabae. Estes resultados ampliam o conhecimento sobre o gênero Ancistrus, o mais derivado da tribo, contribuem para o conhecimento sobre este grupo de peixes e para inferir sobre a evolução cromossômica dos Ancistrini.

Key words: Cytogenetics, NOR, Pericentric inversion, Chromosomal evolution.

\section{Introduction}

The Ancistrini tribe is composed of 29 genera, totaling 217 nominal species, with four genera being represented by monotypical species (Fisch-Muller, 2003). Considering only the Brazilian hydrographic system, this tribe comprises 21 genera and 78 nominal species found mainly in the Amazonian rivers (Sarmento-Soares \& Ingenito, 2007). Ancistrus corresponds to the most diversified genus, presenting 62 described species (Bifi et al., 2009). This group is characterized by a smooth snout and may present a sexual dimorphism in many species, with numerous long and forked barbells in males and sparse and short ones in females. However, new species are being recognized and waiting to be described. In

\footnotetext{
${ }^{1}$ Programa de Pós-Graduação em Genética e Evolução (PPGGEv), Universidade Federal de São Carlos, São Carlos, SP, Brazil. mariottodolina@bol.com.br(SM)

${ }^{2}$ Laboratório de Genética e Citogenética Animal, Instituto de Biociências, Universidade Federal de Mato Grosso, Cuiabá, MT, Brazil. lianocentofante@yahoo.com.br (LC)
} 
fact, the number of described Loricariidae species has risen significantly as a whole in the last years, due to the intensification and refinement of the studies in this family.

Cytogenetics and molecular genetics have been useful tools for clarifying doubts concerning the identification of some species, as well as for proposing phylogenies for a few fish groups. In Ancistrus, these analyses have showed a prominent numerical chromosome diversity, from $2 n=34$ in Ancistrus sp. 1 and Ancistrus sp. 2 in Amazonian rivers (de Oliveira, 2006), to $2 \mathrm{n}=52$ in Hemiancistrus sp. and Panaque cf. nigrolineatus (Artoni \& Bertollo, 2001).

Among Neotropical fish, chromosomal variations directly related to the number and/or size of the nucleolar organizer regions (NORs) are known for many groups, such as Gymnotiformes (Foresti et al., 1981; Almeida-Toledo, 1985), Parodontidae (Moreira-Filho et al., 1984), and Serrasalminae (Galetti et al., 1985), among others. Recently, these variations have been confirmed by the use of fluorescent in situ hybridization (FISH) with 18S rDNA probes (Kavalco et al., 2005; Mantovani et al., 2005; Pazza et al., 2006). However, structural polymorphisms due to other chromosomal rearrangements such as inversions and centric fusions/ fissions are not very common among Neotropical fish, being known mainly among Characiformes (Giuliano-Caetano \& Bertollo, 1988; Cestari \& Galetti Jr.,1992; Centofante et al., 2002; Jorge \& Moreira Filho, 2004; Pazza et al., 2006). In Siluriformes, numerical and/or structural polymorphisms were observed in a few Pimelodidade (Dias \& Foresti, 1993; Vasconcelos \& Martins-Santos, 2000), Heptapteridae (Vissoto et al., 2001; Kavalco et al., 2004), Hypoptopomatinae (Andreata et al., 1994), Loricariinae (Giuliano-Caetano, 1998), and Trichomycteridae species (Borin \& Martins-Santos, 2000).

In the present work, it is described a structural polymorphism in the NOR-bearing chromosomes of Ancistrus cuiabae, revealed by conventional cytogenetic techniques and fluorescent in situ hybridization with an 18S rDNA probe.

\section{Material and Methods}

Fifteen male and fifteen female specimens of Ancistrus cuiabae Knaack, 1999, were cytogenetically studied. The site collection of this species is situated $36 \mathrm{~km}$ away from Poconé (approximately $16^{\circ} 21^{\prime} 21^{\prime \prime} \mathrm{S} 56^{\circ} 27^{\prime} 55^{\prime \prime} \mathrm{W}$ ), in the State of Mato Grosso, Brazil. This location, regionally known as Arrombado, has the characteristics of a bay in the Pantanal region, because it connects to the Bento Gomes River (Paraguay basin) in the flooding season (Fig. 1). These is still no record of this species occurring in any another locality. Voucher specimens were deposited in the fish collection of the Museu de Ciências e Tecnologia da PUC-RS, Porto Alegre (MCP 41979).

The chromosome preparations were obtained by the air drying method (Bertollo et al., 1978). The C-positive band heterochromatin and the Nucleolar Organizer Regions (AgNORs) were detected according to Sumner (1972) and Howell \& Black (1980). The chromosomes were organized into four morphological groups $(\mathrm{m}=$ metacentric, $\mathrm{sm}=$ submetacentric,
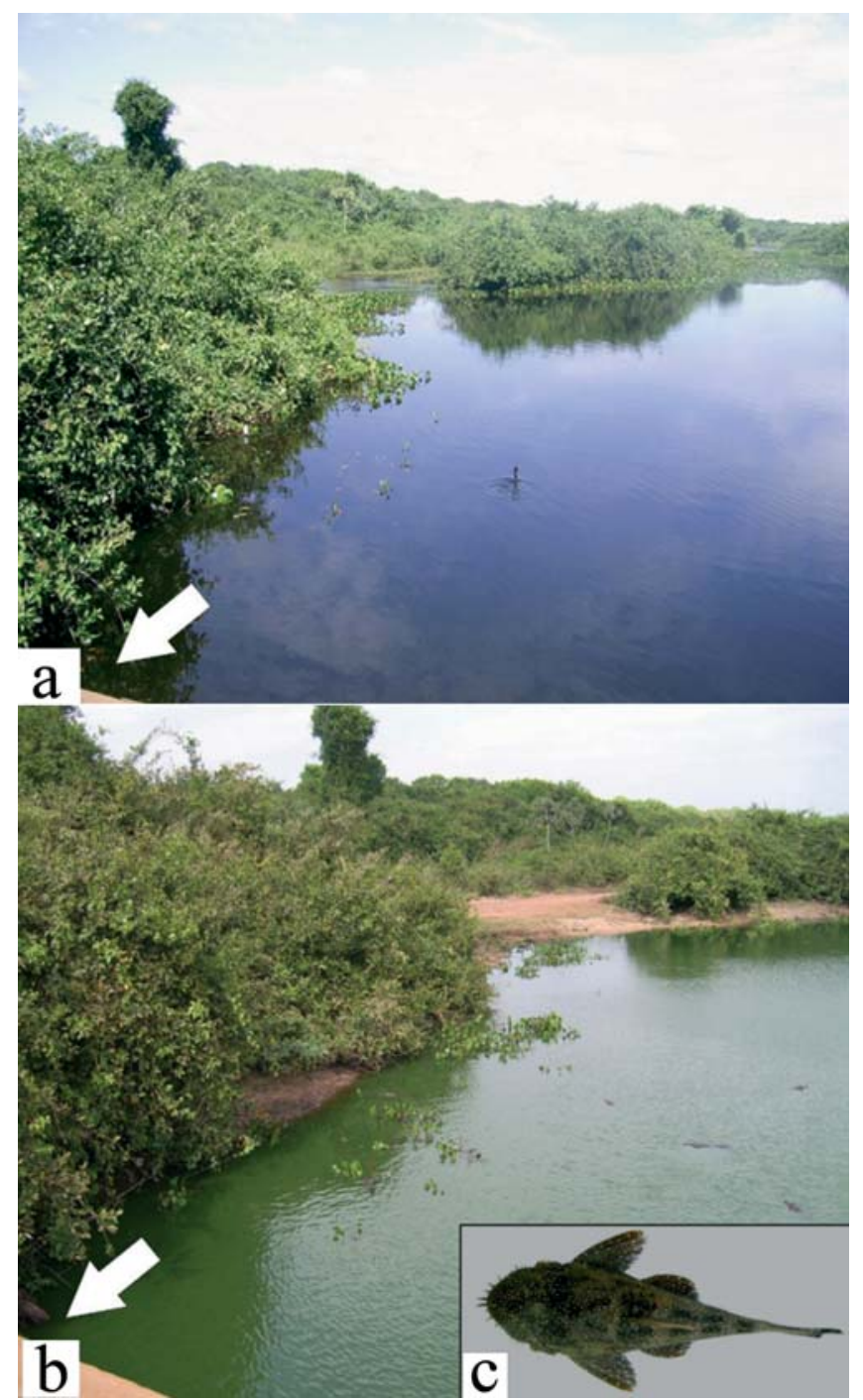

Fig. 1. (a-b) Partial view of the Arrombado bay and the sampling site collection (arrow). (c) Ancistrus cuiabae specimen with $110 \mathrm{~mm}$.

st $=$ subtelocentric, $\mathrm{a}=$ acrocentric $)$ in decreasing order of size, according the arm ratios (Levan et al., 1964). Fluorescent in situ hybridization (FISH) followed the protocol described by Pinkel et al. (1986), using 18S rDNA probes (Hatanaka \& Galetti Jr., 2004).

\section{Results}

All the specimens evidenced the diploid number $2 \mathrm{n}=34$ chromosomes in both sexes, in a sample greater than 1,000 analyzed cells. However, three karyotypic formulae were observed, here named cytotypes A, B and C.

Cytotype A, found in 6 males and 11 females, was characterized by 20m, 8sm and 6st chromosomes and FN (fundamental number or number of chromosome arms) equal to 68 (Fig. 2a). Ag-NORs were observed in the terminal region of the short arms of the second chromosome pair, characterized as metacentric. Fluorescent in situ hybridization results agreed 
with the Ag-NORs locations (Fig. 3a, box).

Cytotype B, detected in 8 males and 4 females, was characterized by 19m, 8sm, 6st, 1a chromosomes and FN = 67 (Fig. 2b). Ag-NORs were evidenced in the terminal region of the short arm of a single metacentric chromosome and the interstitial region of the long arm of a single acrocentric chromosome of the karyotype, which was also corroborated by the FISH data with the 18S rDNA probe (Fig. 3b, box).

Cytotype C, detected in a single male, presented $18 \mathrm{~m}, 8 \mathrm{sm}$, 6st, $2 \mathrm{a}$ chromosomes and FN $=66$. (Fig. 2c). In this case, the Ag-NORs were located in the interstitial region of the long arms of the acrocentric pair, characteristic of this cytotype (Fig. 3c, box).

All cytotypes presented a discrete amount of heterochromatin in the chromosomes, with more prominent C-positive bands adjacent to the NOR regions (Fig. 3 a,b,c).

\section{Discussion}

Loricariidae fish shows a very large variation of the chromosome number as a whole, which ranges from $2 n=80$ in a Hypostomus species (Artoni \& Bertollo, 1996), to $2 n=34$ in Ancistrus species (de Oliveira, 2006; present work). Besides the chromosome number, the karyotypic formula is also variable, showing a differentiated karyotypic evolution throughout the speciation process of this family. Oliveira et al. (1988) considered that the fixation of different chromosome rearrangements would be more likely in populations with reduced vagility, as is the case of some Loricariidae species, thus promoting karyotypic variability.

Alves et al. (2005) suggested that the karyotypic diversity of Loricariidae could be exclusive to Hypostomus, since other loricariid groups seem to be characterized by a relatively conserved diploid number. This opinion was also shared by Lara (1998), Artoni \& Bertollo (2001) and Souza (2003). However, as new studies were performed in Ancistrini it was pointed out that the chromosomal diversity go beyond the previously supposition for this group. Indeed, the Ancistrini tribe is characterized by a chromosomal diversification, especially in the genus Ancistrus where distinct karyotypic structures indicate a probable species complex (Mariotto \& Miyazawa, 2006), besides the occurrence of simple and multiple sex chromosome systems (Mariotto et al., 2004; Mariotto \& Miyazawa, 2006; de Oliveira et al., 2007, 2008), as well as simple or multiple and interstitial or terminal NOR systems (Alves et al., 2003; Mariotto et al., 2004; Souza et al., 2004; Mariotto \& Miyazawa, 2006; de Oliveira et al., 2006).

The data from the present study corroborate the karyotypic diversity of Ancistrus. In fact, the analysis of the three cytotypes detected in A. cuiabae evidenced a case of structural chromosome polymorphism, associated to the NORbearing chromosome pair. This way, while in cytotype A this pair is metacentric, in cytotype B it is composed of a metacentric and an acrocentric chromosome, and in cytotype $\mathrm{C}$ by an acrocentric pair. Cytotype A was the most frequent in the studied sample and, probably, it corresponds to the standard karyotypic form of the species, being present in $57 \%$ of the specimens. On the other hand, cytotype B was detected in $40 \%$ of the specimens, and cytotype $\mathrm{C}$ in only $3 \%$ of the sample. Therefore, it is likely that the observed

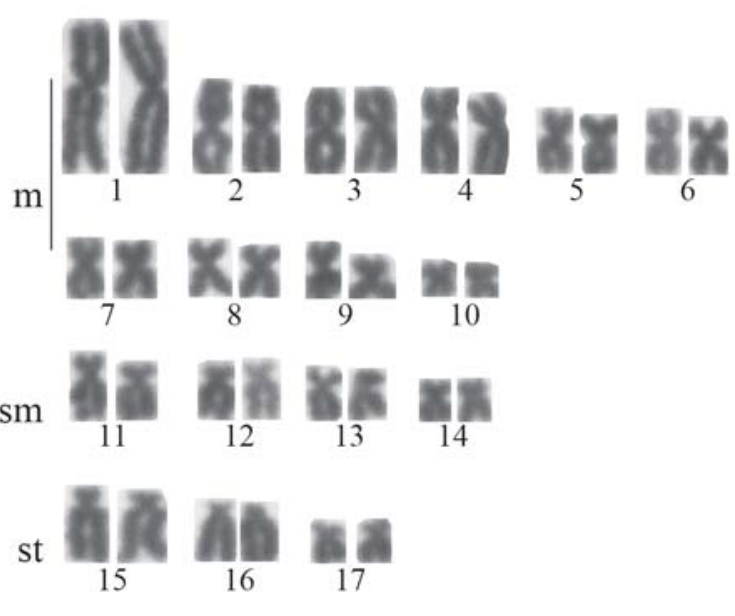

a

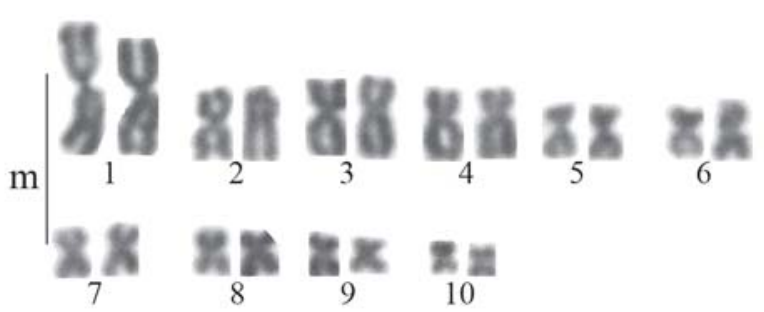

$\mathrm{b}$
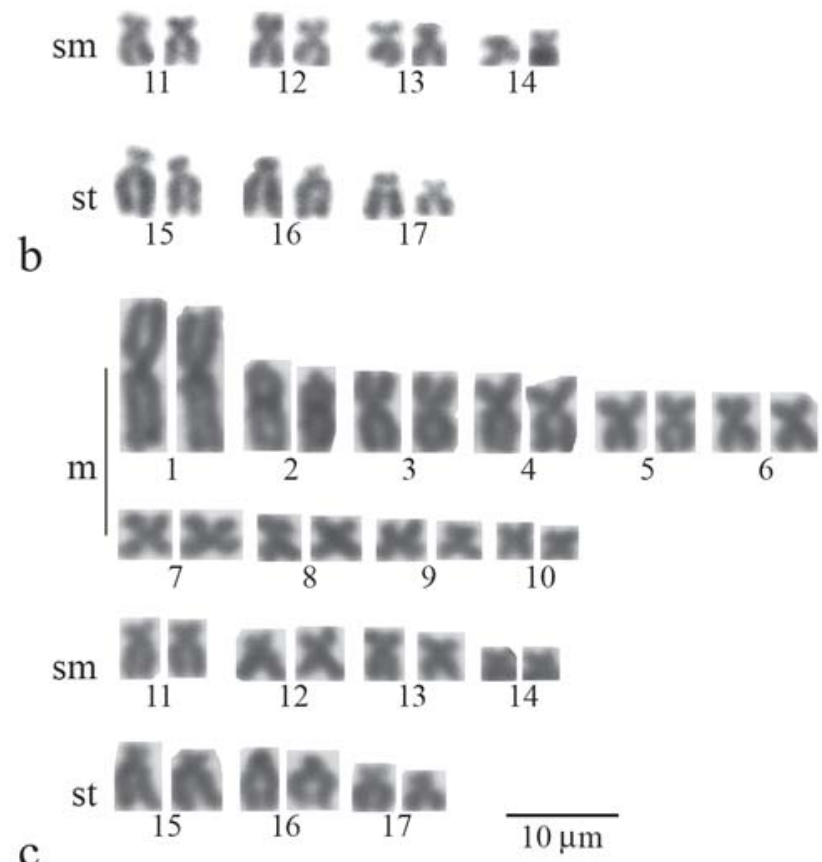

Fig. 2. Karyotypes of Ancistrus cuiabae, after conventional Giemsa staining, showing the polymorphic second chromosome pair. (a) Cytotype A with two metacentric chromosomes, (b) cytotype B with a metacentric and an acrocentric chromosome, and (c) cytotype $\mathrm{C}$ with two acrocentric chromosomes. 
polymorphism is due to pericentric inversions that, at the same time, modified the chromosome form (metacentric/ acrocentric) and the location of the NORs on the chromosomes (terminal/interstitial). Hence, cytotype A would

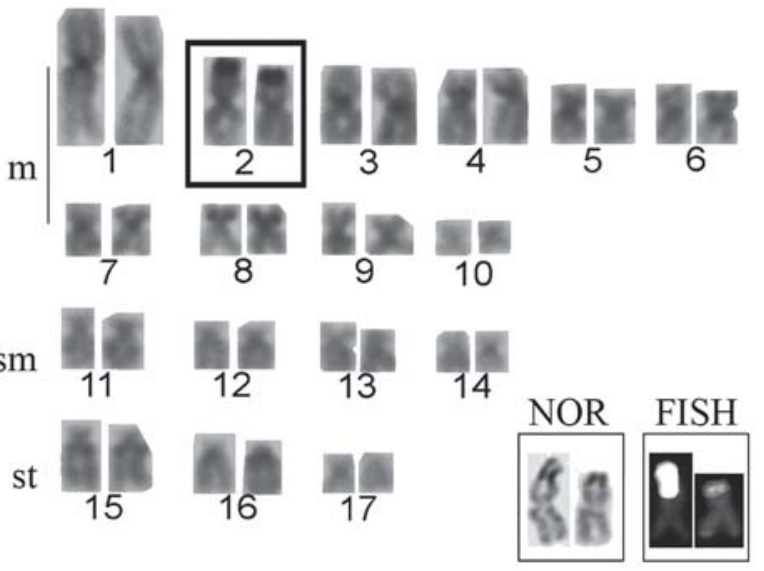

a

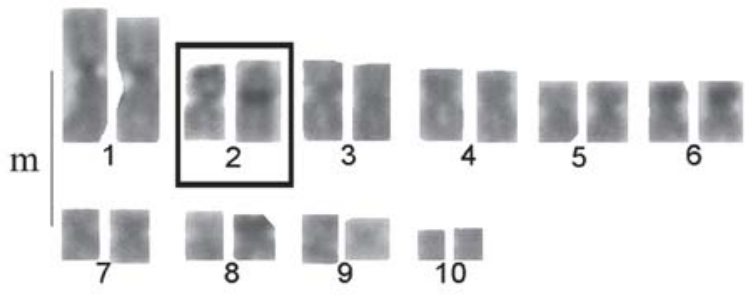

b
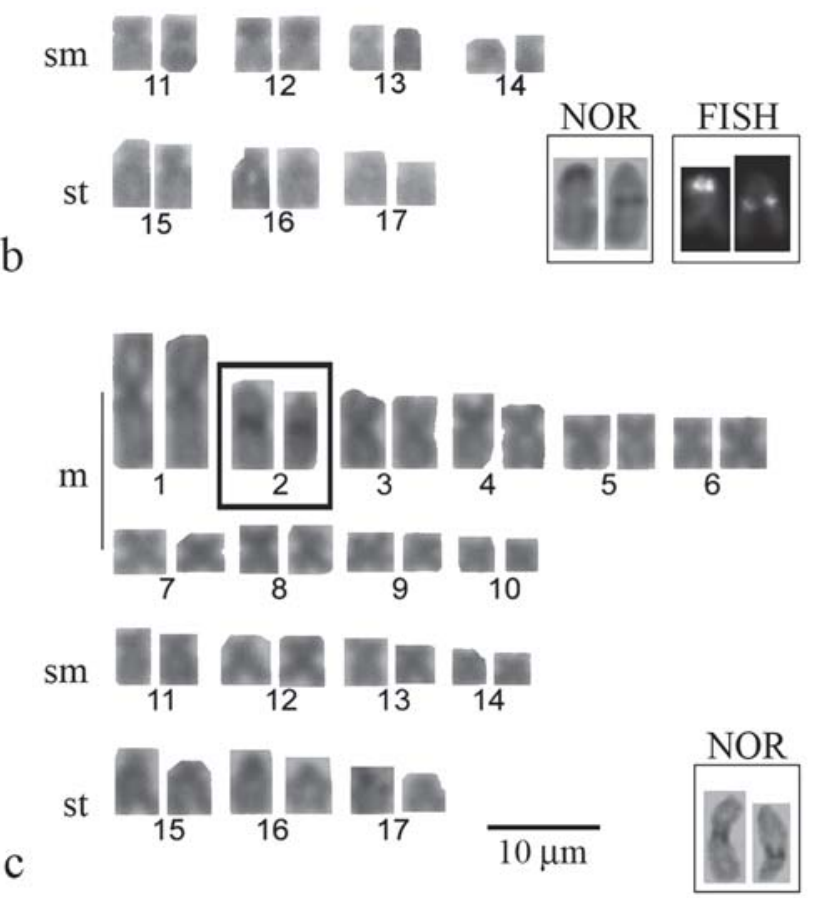

Fig. 3. Karyotypes of Ancistrus cuiabae, after sequential Cbanding, evidencing the C-positive heterochromatin in the cytotypes A (a), B (b) and C (c). In the boxes, chromosomes from the second pair after silver staining and fluorescent in situ hybridization (FISH), showing the Ag-NOR and the $18 \mathrm{~S}$ rDNA sites, respectively. correspond to the basic homozygotes cytotype B to the structural heterozygotes and cytotype $\mathrm{C}$ to the structural homozygotes in the population.

Chromosome polymorphism due to pericentric inversions have already been observed in some fish groups. A pericentric inversion concerning the first karyotypic pair was detected in Serrasalmus spilopleura (Serrasalminae) from the Catalão Lake (Amazon basin), with absence of the structural homozygotes (Centofante et al., 2002). Variations concerning the number of the acrocentric chromosomes in Apareiodon affinis (Parodontidae) from the lower Paraná River (Argentina) were also probably due to pericentric inversions, since the diploid number $(2 \mathrm{n}=54)$ was constant in the population (Jorge \& Moreira-Filho, 2004). Pericentric inversions were also considered in order to explain another few cases of structural polymorphisms, as in Hoplerythrinus unitaeniatus (Erythrinidae) from the Negro River, in the Amazon basin (Giuliano-Caetano \& Bertollo, 1988). On the other hand, very few cases of paracentric inversions are well known in fishes, possibly given the greater difficulty of detection by conventional chromosome analyses. In Apareiodon piracicabae, for example, this rearrangement was considered to explain the occurrence of syntenic double NORs in a chromosome pair of this species (Moreira-Filho et al., 1984; Jesus \& Moreira-Filho, 2000).

A simple NOR system, as present in A. cuiabae, seems to constitute a plesiomorphic condition in Ancistrini, which also occurs in the Hypoptopomatinae, considered a close external group. Therefore, a multiple NOR system, present in a few species of this tribe, such as Peckoltia sp. 1, Peckoltia sp. 2 (Souza, 2003) and Hemiancistrus spilomma (de Oliveira et al., 2006), may represent a derived characteristic for this group. Loricariidae generally possess little heterochromatin, as also found in A. cuiabae, which seems like an ancestral condition for this group. A few exceptions may occur, as in Hypostomus emarginatus, where larger blocks of C-positive bands were verified and coinciding with a higher diploid number, this latter also considered as a derived condition (Artoni, 1996). In A. cuiabae, the C-positive heterochromatin presented a pericentromeric distribution, including the acrocentric chromosomes, which corroborates the role of pericentric inversions originating the polymorphism observed in the population.

Porto-Foresti et al. (2004), detected a NOR polymorphism in Oncorhynchus mykiss from controlled breeding, suggesting that heterozygote individuals would have a greater adaptive value in relation to the homozygote ones. Even though the reduced frequency of cytotype $\mathrm{C}$ may be due to a sampling bias, it is tempting to correlate the distinct frequencies of the A. cuiabae cytotypes with a differential fitness, as suggested for O. mykiss. It is probable that A. cuiabae is restricted to the studied collection site, since it has not been found in other nearby locations or even in rivers of different hydrographic basins. During the dry season, the water level of the bay where the population resides is drastically reduced. In this period, the $A$. cuiabae population must suffer an intensive 
selective pressure from inter-specific competition or predation inside the bay, which loses its connection with the Bento Gomes River. A possible greater adaptability/resistance for such conditions, presented by a specific karyotypic form, could have an important role for the survival of the species, guaranteeing its maintenance in an inhospitable habitat. This is an interesting hypothesis that could be tested in further comparative studies, by comparing the cytotypes frequencies between the favorable and the non-favorable conditions during the dry season.

\section{Acknowledgements}

The authors are grateful to Diones Krinski and John Hall for their help on the paper, and Alexandre Cardoso (FZB/RS) and Tiago Carvalho (University of Louisiana at Lafayette) for the identification of this species. This work was partially supported by FAPEMAT, CNPq and FAPESP.

\section{Literature Cited}

Almeida-Toledo, L. F. 1985. As regiões organizadoras do nucléolo em peixes. Ciência e Cultura, 37(3): 448-453.

Alves, A. L., C. Oliveira \& F. Foresti. 2003. Karyotype variability in eight species of the subfamilies Loricariinae and Ancistrinae (Teleostei, Siluriformes, Loricariidae). Caryologia, 56(1): 57-63.

Alves, A. L., C. Oliveira \& F. Foresti. 2005. Comparative cytogenetic analysis of eleven species of subfamilies Neoplecostominae and Hypostominae (Siluriformes: Loricariidae). Genetica, 124(23): 127-136.

Andreata, A. A., L. F. Almeida-Toledo, C. Oliveira \& S. A. ToledoFilho. 1994. Cytogenetic studies on the subfamily Hypoptopomatinae (Pisces, Siluriformes, Loricariidae). III. Analysis of seven species. Caryologia, 47(1): 27-37.

Artoni, R. F. 1996. Estudos citogenéticos na família Loricariidae, com ênfase no Gênero Hypostomus Lacépède, 1803 (Pisces, Siluriformes). Unpublished MSc. Dissertation, Universidade Federal de São Carlos, São Carlos, 162p.

Artoni, R. F. \& L. A. C. Bertollo. 1996. Cytogenetic studies on Hypostominae (Pisces, Siluriformes, Loricariidae). Considerations on karyotype evolution in the genus Hypostomus. Caryologia, 49(1): 81-90.

Artoni, R. F. \& L. A. C. Bertollo. 2001. Trends in the karyotype evolution of Loricariidae fish (Siluriformes). Hereditas, 134(3): 201-210.

Bertollo, L. A. C., C. S. Takahashi \& O. Moreira-Filho. 1978. Citotaxonomic considerations on Hoplias lacerdae (Pisces, Erythrinidae). Brazilian Journal of Genetics, 1: 103-120.

Bifi, A. G., C. S. Pavanelli \& C. H. Zawadzki. 2009. Three new species of Ancistrus Kner, 1854 (Siluriformes: Loricariidae) from the Rio Iguaçu basin, Paraná State, Brazil. Zootaxa, 2275: 41-59.

Borin, L. A. \& I. C. Martins-Santos. 2000. Intra-individual numerical chromosomal polymorphism in Trichomycterus davisi (Siluriformes, Trichomycteridae) from the Iguaçu River basin in Brazil. Genetics and Molecular Biology, 23(3): 605607.

Centofante, L., J. I. R. Porto \& E. Feldberg. 2002. Chromosomal polymorphism in Serrasalmus spilopleura Kner, 1858 (Characidae, Serrasalminae) from central Amazon Basin. Caryologia, 55(1): 37-45.
Cestari, M. M. \& P. M. Galetti Jr. 1992. Chromosome studies of Serrasalmus spilopleura (Characidae, Serrasalminae) from the Paraná-Paraguai rivers: evolutionary and cytotaxonomic considerations. Copeia, 1992(1): 108-112.

Dias, A. L. \& F. Foresti. 1993. Cytogenetic studies on fishes of the family Pimelodidae (Siluroidei). Revista Brasileira de Genética, 16(3): 585-600.

Fisch-Muller, S. 2003. Subfamily Ancistrinae. Pp. 373-400. Reis, R. E., S. O. Kullander \& C. J. Ferraris, Jr. (Eds.). In: Check list of the freshwater fishes of South and Central America. Porto Alegre, Edipucrs, 729p.

Foresti, F., L. F. Almeida-Toledo \& S. A. Toledo-Filho. 1981. Polymorphic nature of nucleolus organizer regions in fishes. Cytogenetics and Cell Genetics, 31: 137-144.

Galetti Jr., P. M., E. B. Silva \& R. T. Cerminaro. 1985. A multiple NOR system in the fish Serrasalmus spilopleura (Serrasalmidae, Characidae). Brazilian Journal of Genetics, 8(3): 479-484.

Giuliano-Caetano, L. 1998. Polimorfismo cromossômico Robertsoniano em populações de Rineloricari latirostris (Pisces, Loricariinae). Unpublished Ph.D. Dissertation, Universidade Federal de São Carlos, São Carlos, 78p.

Giuliano-Caetano, L. \& L. A. C. Bertollo. 1988. Karyotype variabiity in Hoplerithrinus unitaeniatus (Characiformes, Erythrinidae). I. Chromosome Polymorphism in the Rio Negro Population (Manaus, State of Amazonas). Revista Brasileira de Genética, 11(2): 299-306.

Hatanaka, T. \& P. M. Galetti Jr. 2004. Mapping of the 18 S and 5S ribosomal RNA genes in the fish Prochilodus argenteus Agassiz 1829 (Characiformes, Prochilodontidae). Genetica, 122(3): 239244.

Howell, W. M. \& D. A. Black. 1980. Controlled silver-staining of nucleolus organizer regions whit a protective coloidae developer: a l-step method. Experientia, 36: 1014-1015.

Jesus, C. M. \& O. Moreira-Filho. 2000. Cytogenetic studies in some Apareiodon species (Pisces, Parodontidae). Cytologia, 65: 397-402.

Jorge, L. C. \& O. Moreira-Filho. 2004. Nucleolar organizer regions as markers of chromosomal polymorphism in Apareiodon affinis (Pisces, Parodontidae). Caryologia, 57(2): 195-199.

Kavalco, K. F., R. Pazza, L. A. C. Bertollo \& O. Moreira-Filho. 2004. Heterochromatin characterization of four fish species of the family Loricariidae (Siluriformes). Hereditas, 141(3): 237-242.

Kavalco, K. F., R. Pazza, L. A. C. Bertollo \& O. Moreira-Filho. 2005. Karyotypic diversity and evolution of Loricariidae (Pisces, Siluriformes). Heredity, 94(2): 180-186.

Lara, M. C. S. 1998. Aspectos citogenéticos de quatro espécies de peixes da subfamília Ancistrinae (Siluriformes, Loricariidae) da Bacia do Rio Paraná. Unpublished MSc. Dissertation, Universidade Estadual de Maringá, Maringá, 51p.

Levan, A., K. Fredga \& A. A. Sandberg. 1964. Nomenclature for centromeric position on chromosomes. Hereditas, 52(2): 201220.

Mantovani, M., L. D. S. Abel \& O. Moreira-Filho. 2005. Conserved $5 \mathrm{~S}$ and variable 45S rDNA chromosomal localization revealed by FISH in Astyanax scabripinnis (Pisces, Characidae). Genetica, 123(3): 211-216.

Mariotto, S., R. F. Artoni \& C. S Miyazawa. 2004. Occurrence of sex chromosomes of the type ZZ/ZW in Ancistrus cf. dubius (Loricariidae, Ancistrinae) of the Paraguay River Basin, Mato Grosso, Brazil. Caryologia, 57(4): 327-331. 
Mariotto, S. \& C. S. Miyazawa. 2006. Ancistrus cf. dubius (Siluriformes, Ancistrinae), a complex of species. 1. Chromosomal characterization of four populations and occurrence of sex chromosomes of the type $\mathrm{XX} / \mathrm{XY}$, in the Pantanal Basin of Mato Grosso, Brazil. Caryologia, 59(4): 299-304.

Moreira-Filho, O., L. A. C. Bertollo \& P. M. Galetti Jr. 1984. Structure and variability of nucleolar organizer regions in Parodontidae fish. Canadian Journal of Genetics and Cytology, 26(5): 564-568.

Oliveira, C., L. F. Almeida-Toledo, F. Foresti, H. A. Britski \& S. A. Toledo-Filho. 1988. Chromosome formulae of neotropical freshwater fishes. Brazilian Journal of Genetics, 11: 577-624.

de Oliveira, R. R., E. Feldberg, M. B. Anjos \& J. Zuanon. 2007. Karyotype characterization and ZZ/ZW sex chromosomes heteromorphism in two species of the catfish genus Ancistrus Kner, 1854 (Siluriformes:Loricariidae) from the Amazon basin. Neotropical Ichthyology, 5(3): 301-306.

de Oliveira, R. R., E. Feldberg, M. B. Anjos \& J. Zuanon. 2008. Occurrence of multiple sexual chromosomes (XX/XY1Y2 and Z1Z1Z2Z2/Z1Z2W1W2) in catfishes of the genus Ancistrus (Siluriformes, Loricariidae) from the Amazon Basin. Genetica, 134(2): 243-249.

de Oliveira, R. R., I. L. Souza \& P. C. Venere. 2006. Karyotype description of three species of Loricariidae (Siluriformes) and occurrence of the ZZ/ZW sexual system in Hemiancistrus spilomma Cardoso \& Lucinda, 2003. Neotropical Ichthyology, 4(1): 93-97.

Pazza, R., K. F. Kavalco \& L. A. C. Bertollo. 2006. Chromosome polymorphism in Astyanax fasciatus (Teleostei, Characidae). 1. Karyotype analysis, Ag-NORs and mapping of the $18 \mathrm{~S}$ and $5 \mathrm{~S}$ ribosomal genes in sympatric karyotypes and their possible hybrid forms. Cytogenetic and Genome Research, 112: 313319.

Pinkel, D., T. Straume \& J. W. Gray. 1986. Cytogenetic analysis using quantitative, high-sensitivity, fluorescence hybridization. Proceedings of the National Academy of Sciences of the United States of America, 83: 2934-2938.

Porto-Foresti, F., C. Oliveira, E. A. Gomes, Y. A. Tabata, M. G. Rigolino \& F. Foresti. 2004. A lethal effect associated with polymorphism of the NOR-bearing chromosomes in rainbow trout (Oncorhynchus mykiss). Genetics and Molecular Biology, 27: 51-54.

Sarmento-Soares, L. M. \& L. F. S. Ingenito. 2007. Ancistrinae. Pp. 98-102. In: Buckup, P. A., N. A. Menezes \& M. S. Ghazzi (Orgs.). Catálogo das Espécies de Peixes de Água Doce do Brasil. Rio de Janeiro, Museu Nacional, 195p.

Souza, A. C. P. 2003. Descrição cariotípica de peixes dos gêneros Baryancistrus, Parancistrus, Peckoltia e Ancistrus (Ancistrinae, Loricariidae) da Bacia Amazônica. Unpublished MSc. Dissertation. Universidade Federal do Pará, Belém, 130p.

Souza, A. C. P., A. L. Nascimento, J. R. Carvalho Jr., R. M. S. Barros, E. Feldberg, C. Y. Nagamachi \& J. C. Pieczarka. 2004. Karyotypic analysis of Baryancistrus aff. niveatus (Ancistrinae, Loricariidae) by C-banding, ag-NOR, CMA3, DAPI and FISH. Caryologia, 57(3): 219-223.

Sumner, A. T. 1972. A simple technique for demonstrating centromeric heterochromatin. Experimental Cell Research, 75: 304-306.

Vasconcelos, C. \& I. C. Martins-Santos. 2000. Chromosome polymorphism in species of the Pimelodidae family (Pisces, Siluriformes). Hereditas, 132: 103-109.
Vissotto, P. C, F. Foresti \& C. Oliveira. 2001. Karyotypic characterization of two species of the genus Imparfinis (Teleostei, Siluriformes, Heptapteridae). Chromosome Science, 5: 97-103.

Accepted October 28, 2009

Published December 18, 2009 